\title{
Analysis of a management modelof conflicts uses of natural resources in Lake Fitri in Chad
}

\author{
NdoutorlengarMédard, OulonaEsaïe, BallahSolkam Rosalie \\ Department of geographyUniversity ofSarh, Chad; Department of geographyUniversity of Ndjamena, Chad; \\ Department of geographyUniversity of Sarh, Chad
}

\begin{abstract}
The inexistence, the insufficiency, the laxity in the application of the regulatory texts and their superposition with those of the religious confessions in many African countries give free course to a multiplicity of the actors and a diversification of the modes of management of the conflicts of use of the natural resources (LE BRIS E. and al, 1982;BOUTNA, A., 2007).Such is the case of Chad where the ambiguity of the land rights and the simultaneous application of those traditional and Islamic create more problems than to solve them (ARMI J., 2005;KOYOUMTAN Agard 2002).This work analyzes the mode of management of the conflicts around the Lake Fitri which contains various actors of production coming from all the areas of the country and even beyond the borders and thus of several religious confessions because of the biodiversity of the aforementioned zone which offers beneficial halieutics andagropastoralpotentialities.It was made possible thanks to the financial support of the project "GrandsEcosystèmesLacustres" (GELT) which made it possible to carry out investigations, direct observations and to take part in certain meetings of resolution of the conflicts.
\end{abstract}

Key words:natural-conflict-agriculture-breeding-fishing-rural lake Fitri-resources.

\section{INTRODUCTION}

From his geographical position and according to intensity of the socio-economic activities of men, one can divide Chad into two parts.From the center towards the South, where the annual quantities of the recorded rains evolve from 500 to $1200 \mathrm{~mm}$, the favorable climatic conditions allow diffused activities in space.It is the useful part of the country (Magrin G, 2002).But in the opposed direction, the climate passes from Sahelian to the Saharan one.The rainfall decreases until giving zero values at the Northern end of the country. The climatic austerity of this part of the country conditions human activities (BAOHOUTOU L, 2007). These last are summarized in the favorable mediums which are the wadis, the oases and the lakes where men and animals are constrained to share space and the resources.But, very often, this demographic concentration leads to promiscuity (BANDOUMAL, O 2004).

The department of Fitri in the area of Batha is an example of the favorable zones of this part of Chad from the climatic conditions and the socio-economic potentialities that the presence of the lake confers to him.Located in the sub-prefecture of Yao, the lake Fitri extends in a very plane area between 285 and $290 \mathrm{~m}$ from altitude with flooded surfaces which thus vary from one year to another according to the abundance of precipitations and the hydrous contributions of the bahrs(Bachimon and $\mathrm{Al}$, 2005). It takesthe second position in the classification of the most significantlake extents of the country. Its surface varies between 420 and 1,300 $\mathrm{km}^{2}$ (during the exceptional years) with a volume estimated at a billion cubic meter of water in rain season, and can sometimes be wider.

Figure 1:Administrative Area division of Batha/SIDRAT-2012

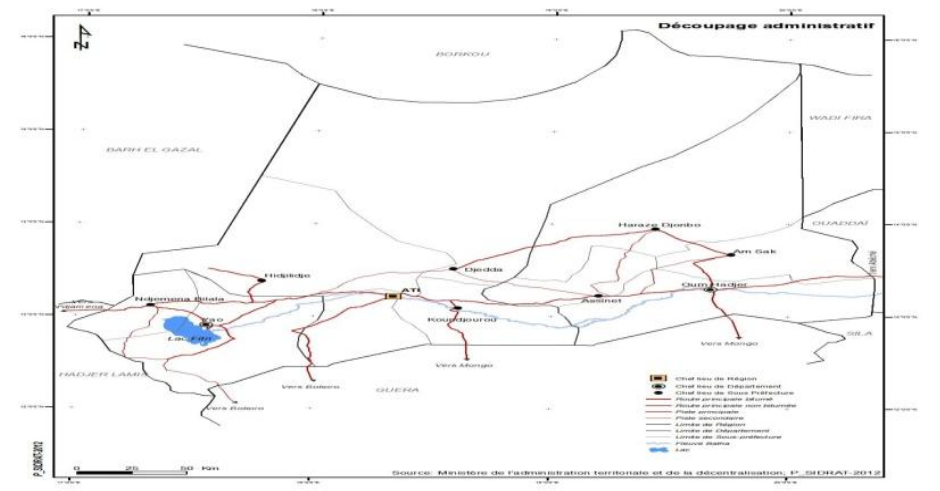


The lake givesfavorable conditions at the same time to agriculture, breeding and fishing in any season of the year from where the massive arrival in the zone of the people of all the horizons. The natural resources' sharing usually generates conflicts of which the resolutions are, often, difficult because of the diversity of ethnics group, habits, right and arbitration boards (DJIKOLOUM, B.B., 2004).

\section{MATERIALS AND METHOD}

The method of data acquisition, which helped us to carry out this work, is based primarily on the investigations, the direct observations of ground thanks to the participations in the meetings of resolution of the conflicts as well by the authorities concerned with the public authorities and the traditional authorities.

Investigations:they were carried out by using a card prepared for the circumstance. This one takes into account the nature of the actors, conflicts and their management on the one hand, the devices of prevention and the mechanisms of their management by nature of actors and managers of the conflicts together with that of de jure system. The modes of research of the damage authors and compensations were not lost sight of the fact. The investigations were managed with all the categories of producers. On the whole 180 people were surveyed during the data acquisitions. The agricultural producers (of culture rain, of counter-season and market-gardeners) account for $52 \%$ of the sample because of the diversity of their category. The stockbreeders and the fishermen come after them respectively to a total value of $18.7 \%$ and $22.9 \%$. The reasons that justify their low representativeness in the sample come on the one hand from their mobility and on the other hand from theunicity of their practice even if the herds vary in species and in quantity.

The direct observations of ground are those during which we carried out investigations near the authorities charged to manage the conflicts. Their dispersion in time (frequency of conflicts and days of judgment) and in space (points of judgment and its accessibility) reduced considerably their representativeness in the sample. They represent $6.4 \%$ of them.

\section{RESULTS AND DISCUSSIONS}

The multifonctionnality of the zone and the multiactivity make show many conflicts which vary according to origins, implied actors, ranges and actors of management.

\subsection{Typology of the actors and conflicts in the Lake Fitri}

The presence of the lake Fitri in the medium of the Chadian Sahelconfers to the zone a microclimate favorable to a pluriactivity (DAGOU P. and Al).Certain activities follow one another in time and in space and others overlap.Because of the permanent presence of water, peasants can go from the rain culture to the truck farming while passing by the culture of counter-season.It can happen that peasants practice at the same time agriculture, breeding and fishing. The greenery also leads other stockbreeders to share in common a multiplicity of actors on the same space.

Table 1:Distribution actors according to origin, space, type and frequency

\begin{tabular}{|l|l|l|l|c|}
\hline \multicolumn{1}{|c|}{ Actors } & \multicolumn{1}{|c|}{ Origin } & \multicolumn{1}{c|}{ Spaces } & \multicolumn{1}{c|}{ Type ofconflicts } & Fréquency \\
\hline Farmers/farmers & Share of grounds & $\begin{array}{l}\text { Villages } \\
\text { andFields }\end{array}$ & communautary & ++++ \\
\hline Farmer/stockbreeders & $\begin{array}{l}\text { Share grazing } \\
\text { grounds and } \\
\text { pasture }\end{array}$ & $\begin{array}{l}\text { Villages and } \\
\text { Fields }\end{array}$ & Intercommunautary & ++++ \\
\hline $\begin{array}{l}\text { Stockbreeders/ } \\
\text { stockbreeders }\end{array}$ & $\begin{array}{l}\text { Share grazing } \\
\text { grounds and } \\
\text { pasture }\end{array}$ & $\begin{array}{l}\text { Water points, } \\
\text { pasture and } \\
\text { cattle market }\end{array}$ & communautary & ++ \\
\hline Stockbreeder/fishermen & $\begin{array}{l}\text { Management of } \\
\text { bordering spaces } \\
\text { and crossed } \\
\text { towards the } \\
\text { islands }\end{array}$ & Banks, water & intercommunautary & + \\
\hline Fisherman-fishermen & $\begin{array}{l}\text { Shareof space, } \\
\text { destruction of } \\
\text { fish materials }\end{array}$ & Banks, water & Communautary & + \\
\hline $\begin{array}{l}\text { users/ Decentralized } \\
\text { Service of the State }\end{array}$ & $\begin{array}{l}\text { Partial jugement, } \\
\text { repression }\end{array}$ & Diffused & Nonopenconflict & +++ \\
\hline
\end{tabular}

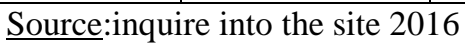


The thread of interests of ones and the others in the village, of fields, of pastures, on water, at the edge of the lake for various reasons leads to conflicts (MARTY and Al, 2010;ZAKINET D., I, 2008).

The intra professional category conflictsare often Communal.Between farmer and farmers, stockbreeder and stockbreeders or fishermen and fishermen, the frequency of the conflicts is careless and their demonstrations are less violent because, either of their professional affinity and/or tribal andsometimes religious.But between two professional categories, they oppose two different societies from their customs and habits and sometimes from various religious confessions. The frequency is higher and the forms of demonstrations are violent in this case. They can also oppose the decentralized services of the State to the various users of natural resources. The resolution of these conflicts depends on the arbitration boards too.

\subsection{Principal arbitration boards of the conflicts}

Following the example of the country, there is multiple arbitration board of conflicts in the area (DANGAR, Y. M., 2006). This pluralism is the result of Fitri history, the colonial heritage and strong islamization of the populations. The zone of study was and remains a sultanate. At the head of this one an uncontested Sultan by the population reigns.He is represented in the villages by the boulama or Kaïdhala.Thus, the minor conflicts in the villages are treated by the latter which then return account to the Sultan. The management of the conflict is transferred to him to the authorities higher when those cannot solve it.The major conflicts which lead to deaths of men or intercommunity are under the direct responsibility of the Sultanate (HAGUENBUCHER, F, 1968;KAIDALLAH, M. H., 1985)

Apart from the authority of traditional judgment, we can also find the authority of moslems, of administrative and military services of the state. In the first case, the imams, the Sheiks, the Heads of ferricks and Khachimbet have the capacity to solve the problems.In the authorities of resolutions of the official administration, the Prefects, the Sub-prefects, the commanders of gendarmerie squads, research and territorial safety are the authorized voices, in this case, to pronounce a judgment.

Each arbitration board has specific competences to resolve conflicts. And the decision of an actor or a group of actors to carry a conflict to the arbitration of a given jurisdictional institution rather than to such other is not made in a fortuitous way.Indeed, the actors tend to solicit, initially, the jurisdiction from which they hope to obtain satisfaction following the process of arbitration. This choice depends on the resources available to the plaintiff, namely his economic, relational and cognitivecapital.The cognitive capital are the theoretical and empirical knowledge which an individual has on the operation of an arbitration board given.

The trajectories of the conflicts combine at the same time the usual and official arbitration boards without guaranteeing their final resolution. When an authority cannot solve a disagreement, other authorities are needed However, certain civil cases carried in front of the military authorities are referred to the sultan.

\subsection{Process of resolution of conflicts.}

It takes into account the search for authors of fixed prices, the evaluation of damages and the modes of resolution of conflicts.

\subsubsection{The search for authors of infringement}

In the absence of a modern mechanism and means, the authors of the crimes are required in the zone by a traditional method when they are not taken, red handed, on the spot of the infringement.It is a system which consists with the identification of the footprint of the people and even of the animals'hooves.

In the absence of the obvious offence, any person or animal present at the neighborhoods of the places is supposed to be the author of the infringement.Otherwise the identification of the imprints help to suspect the author.On the contrary side, the follow-up of the tracks leads towards the residence of the person or the camping of the stockbreeders.But when the tracks of the animal neither lead to a wandering herd, nor on a camping, the stockbreeders located in the surroundings of the field are collectively accused.The suspected people have the responsibility to find the real culprit. On the contrary case, the responsibility becomes collective. The last recourse, if the first processes do not succeed, is to make swear on the Holy Book the people in the delimited neighborhoods.

The procedure of search of authors of the damage by the identification of the footprint and/or by the follow-up of the tracks is very aleatory and can carry blurs for several reasons, in our point of view. Initially, the feet and the shoes can resemble each other to be able to reveal the identity of only one person. Even if in certain African villages the inhabitants almost know each other and very little have the means to buy the same shoes.In the second place, it is easy to be mistaken in the follow-up oftracks of people and animals.Indeed, the identifier can confuse the traces if many people or animals had suddenly passed on the way after the infringement.While following, it can thus lead on an innocent in the neighborhoods or a camping, a village which do not even shelter the required author.Lastly, the Holy Book of Islam is not admitted by people of other religious confessions who will take this way as an affront. 


\subsubsection{The evaluation of damage}

Practiced in all the arbitration boards, it is often entrusted to the technicians of agriculture, breeding, fishing or of the agents of forestry commission according to cases'. The evaluation of damage by the indicated technician rests on criteria which take into account damaged surface, the concerned culture, the size of the plants, the production and the selling price by kilogram of the product on the market.

It is easier to make an evaluation in the agricultural sector than the others because of the existing local principles.And the protagonists in these types of conflicts are farmers and stockbreeders. The causes of conflicts are mainly the destruction of the seedlings and/or the products in the camp of the farmers. The system of compensation for the seedlings differs from that of the agricultural products.For the cultivated species such as bean and gombo, a young destroyed seedling is compensated at a rate of $75 \mathrm{~F}$ per stool, an average seedling is paid $125 \mathrm{~F}$ and a seedling with maturity to $250 \mathrm{~F}$ the torn off seedling from the grounds costs $1,500 \mathrm{~F}$ to the author per stool.The case of cereals and especially berbéré is particular:5 destroyed panicles equivalent toa coro, a measuring unit being worth $2.5 \mathrm{~kg}$, by way of damages.

This mode of compensation can have a soft tone when the conflict opposes two people of the same community.Because of the possibility of the rejuvenation of the young seedlings if they are not uprooted, for a field mended of in the more months, the stockbreeder pays the value of the destroyed seedbeds or the seedbeds for possible replacements.Beyond one month, the sorghums are in montaison and the stockbreeder must pay the number of bags which the peasant would produce in normal time in the event of total destruction. For the red sorghum, 7 grazed ears equivalent to a coro of damages.

In the camp of the stockbreeders, the causes of the conflicts are the acts of cruelty on the animals which are the responses leaded by the recidivism of the infringement. These acts can be the cases of wounds made on the animals or slaughter.They are very rare cases but, as well as the farmers, the stockbreeders claim repair.For a killed sheep, the author of the crime spends between 25000 and 50000 of francs CFA. An ox killed costs more or less 200,000 FCFA.This evaluation takes into account the size of the animal and the approximate estimated price on the market.

In the halieutic sector the causes of the conflicts are mainly the destruction of the nets in water and the trampling of fish by the cattle on the banks. The direct or indirect authors are held to pay in kind or in cash the damage.Agard (2002) gives a cost located in the range of 7,500 to 8,500 F CFA with regard to the nets. Whereas the roller of wire costs $1,500 \mathrm{~F}$ on the market.On the other hand for fish, the amount to be paid varies according to the species and the size. A tilapia is worth $25 \mathrm{~F}$, a clarias $250 \mathrm{~F}$, a protopterus $500 \mathrm{~F}$.

It is in the forest sector that the evaluation of the damage seems to be ignored in the profit of the sanctions.Indeed since 2008, following the realization of the progress of desert, the higher authorities restricted the cash withdrawal on the environment whose forest component comes in first position on all the extent of the territory.In this logic of the environmental protection, the populations are only authorized to use the deadwood for domestic energy.But to make charcoal, men make recourse to fresh wood. To dissuade people, any person the fines go from 25.000 to 100.000 F CFA.It is the same case for the stockbreeders who change the system of pasture by cutting down trees to nourish their herds as the photography indicates it here below..

Photography 1

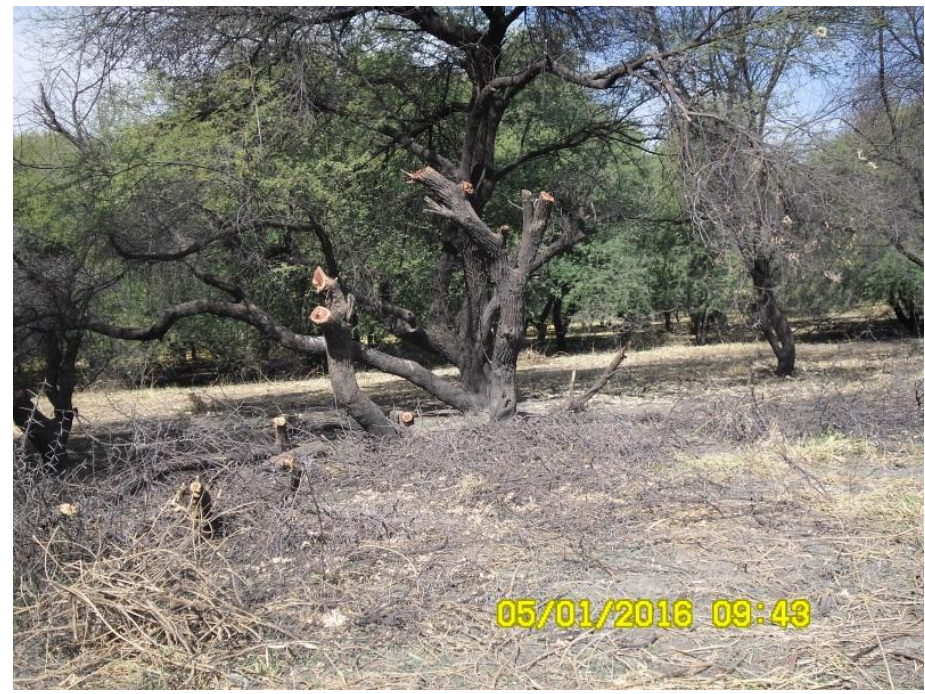

This new shape of pasture of the herds is one of the most harmful practices to nature owing to the fact that people always taste it and at several places at the same time)

Stereotypes:OULENA Esaie, 2016 
After evaluation of the damage then the comesrefunding which is the most difficult step in the resolutions of the conflicts of use.The difficulties come, initially, from the time and granted deadline and method to the accused to carry out the compensation and for his will to honorthe engagement.They come secondly from the type of rights applied in the resolution of conflicts.For there are several modes of resolution of conflicts attached each one to a right whose assets and limits are distinguished each other.

\subsubsection{Modes of resolution of conflicts}

The modes of resolution of conflicts in practice in the zone depend on the arbitration boards and the types of rights applied (CEFOD, 2004). Their assets facilitate while their constraints limit the resolution of the conflicts.

Table 2:Traditionalmodels:assets and limits

\begin{tabular}{|l|l|l|l|}
\hline Mode of résolution & Law used & Assets & Limits \\
\hline $\begin{array}{l}\text { In front of the } \\
\text { traditional heads }\end{array}$ & $\begin{array}{l}\text { Traditionallaw } \\
\text { Islamiclaw }\end{array}$ & $\begin{array}{l}\text { Maintenance of social } \\
\text { cohesion }\end{array}$ & Partiality in the judgement \\
\hline $\begin{array}{l}\text { In front of the } \\
\text { administrative or } \\
\text { military authority }\end{array}$ & $\begin{array}{l}\text { Modern law } \\
\text { Traditional law } \\
\text { Islamic law }\end{array}$ & Expeditious & $\begin{array}{l}\text { Swindle, arbitrary } \\
\text { amends }\end{array}$ \\
\hline By consensus & $\begin{array}{l}\text { Traditionallaw } \\
\text { Islamiclaw }\end{array}$ & $\begin{array}{l}\text { Maintenance of social } \\
\text { cohesion }\end{array}$ & Denominationaldifferences \\
\hline
\end{tabular}

Source: Report of DOPSSPstudy, 2010.

The administrative or military authorities are not the authorities of resolution neither of choice nor preferably of the actors put in concert. They are the recourse in the case of intercommunity conflicts and others had leadedto loss of human lives. Their strong percentage in the modes of resolution of conflicts, as the figure shows it here below concerns on the one hand their rapidaverage of intervention and on the other hand of the importance of the open conflicts and with loss in human lives.

They are considered expeditious in the resolution of the conflicts. But this expeditivity does not miss blurs. One of the first is the arbitrary fine.Indeed, though the damage is evaluated by the amoung of repairs is exaggeratedly fixed and it is from five to ten times superior to the evaluated.All means are used to force the supposed guilty one to be carried out.A fine is inflicted at the same time to the plaintiff and to the accused.It is what gives place to speak about the swindle. Secondly we can say that the modes of resolution of the conflicts by the administrative authorities and soldiers in respect of the texts in practice in the country.The fines are fixed according to the heads and the relations between judge and part.A condemned can spend days in the local prisons without being transferred in a prison which the jurisdiction concerns.

The resolution of the conflicts by consensus is the mode through which the producers of the zone resign themselves to avoid the abuses such as thehigher fines and the high percentage taken from each others on the fines inflicted with the parts implied in the conflict by the administrative and military authorities on the one hand and favoritism on the other hand.The most observed are those which result from the conflicts of intra professional categories. The consensus is oftenbrought from the attitudes each one at the beginning of the conflicts.It is the recourse when the conflict does not leadto the loss of human lives.It can be done directly and simply between the concerned or on the level of the customary heads who, most of the time privilege the maintenance of the social cohesion of the populations instead of the pecuniary considerations. However the limits of resolution per consensus remain the denominational and ethnic differences because of pluralism of rights used and the application of the "Dia" which wants to be at the same time a traditional and modern practice (CLAUDE D., 2002).

The "dia" meaning "price of blood" from the Chadian Arabic is a Moslem practice according to which the parents of an unspecified killed person during a combat can be calmed.According to the tradition, it remains until nowadaysinto practice in Fitri where the population is strongly Moslem.It consists of an amount of money that the author or the parents of this one give to the parents of the victim the next-day after the murder.As long as the dia is not paid to the victims parts, violences cannot stop in spite of the intervention of the police force. The complexity of the dia lies in the diversity of its value according to the ethnic groups, its application even in the nonMoslem mediums and expiries'.Indeed, its value varies from an ethnic group to another as if people do not have the same value in front of the law.It goes from 200,000 to 1,500,000 F CFA.The height is reserved for the ethnic groups such as Zagawa and Gourane which are respectively those of the current President of the Republic and the one that precededhim. The non-Moslems and the other ethnic groups are disadvantaged.For the stockbreeders the compensation is done per capita of oxen. The fine is seventy oxen when one man is killed and the half amount if is one woman. As there is not half person, one boy is equivalent to one man and one young girl is equivalent to one woman. 
The compensation can be done in several sections in time for certain ethnic groups then integrality is required for others within a time which does not exceed three days after the death for others. The non-observance of this time extends and prolongs the conflicts face to which the administrative and military authorities are often unable leading other victims. The insufficiencies and the limits of these various modes of resolution are in themselves other sources of antagonism (SOUGNABE, P. 2004). The people who were disadvantaged or repressed prefer to give justice to themselves.For example the oxen surprised in the fields are cruelly wounded by the owners of the aforesaid fields and the parents of the victims in position of inferiority choose to also kill a person in the family of the criminal.

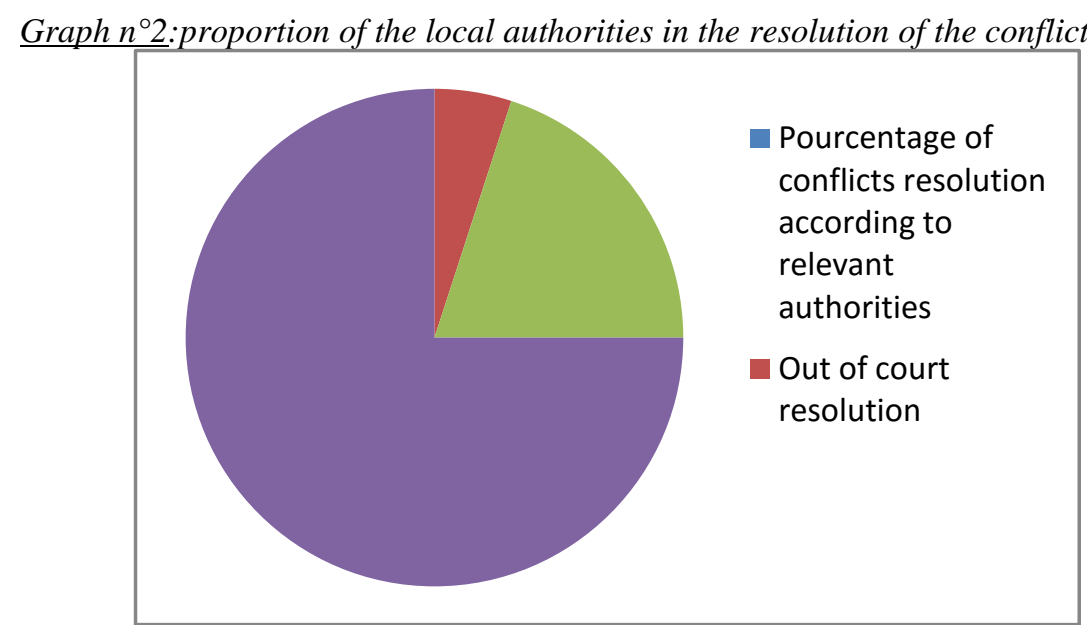

Source:inquire into the site 2016

This graph shows the strong implication of the administrative or military authorities in the resolution of the conflicts in Fitri. Of all these regulated conflicts, those which oppose the farmers and the stockbreeders because of the damage in the fields remain dominant.The gendarmerie squad is more and more solicited by the farmers who regard this authority as repressive even if, the latter always do not manage to perceive the entirety of the damages.

\section{CONCLUSION}

For a zone with cosmopolitan population like the department of Fitri, the existence of arbitration boards of the conflicts of use can only be salutary.But their plurality and the superposition of the rights is sometimes at the origin of the degeneration of the conflicts. The procedure of resolution of the conflicts remains partly traditional because the customary principles of justice dominate the modern right.Certain people prefer to refer only to the authorities who use their tradition instead of another.Or they refuse to obey to the injunctions which come from the unfavorable camp.The result is frustrations and dissatisfactions. The extreme cases are when the injured and disadvantaged people take justice to themselves. This way doing things amplifies the conflicts making, thereafter, difficult the cohabitation of the populations which are however condemned to live together. At this point the higher authorities of the country are challenged.The principal works to be carried out firstly consists of revisiting the texts for its harmonization. The recognition of legality of the human values in front of the laws to fight against the form of justice at two speeds which prevails in Chad in general andparticularly in the zone constitutes a second axis of phenomenon.Finally, the installation of a mechanism of follow-up and repression of the blurs would reduce the forms of exaggerations and arbitrary fines

\section{BIBLIOGRAPHICALREFERENCES}

[1] ARMI, Jonas (2005). La question foncière et les relations intercommunautaires au Tchad : cas de la région de Mayo-Kebbi $\left(\mathrm{XIX}^{\mathrm{e}}-\mathrm{XX}^{\mathrm{e}} \mathrm{S}\right)$. Mémoire de master en Histoire, Université de N'Gaoundéré, 61 pages.

[2] ATLAS du Tchad (2006). Les Editions Jeune-Afrique, Paris, 1 ère édition.

[3] BACHIMON P., COUREL M.F., DAGOU P., 2005. Etude des géosystèmes des lacs Fitri et Léré. Projet CAMPUS Tchad. PRODIG. 73 p.

[4] BANDOUMAL, O. (2004). Démographie et Questions Foncières au Tchad. Contribution au colloque sur la question foncière au Tchad, CEFOD, p 141- 158.

[5] BAOHOUTOU, L. (2007). Les conflits agriculteurs/éleveurs : premier produit de l'impact du climat sur l'élevage in Les précipitations en zone soudanienne du Tchad durant les quatre dernières décennies (1960-1999) : variabilités et impacts. Thèse de Géographie, Université de Nice, 231 pages. 
[6] BOUTNA, A. (2007). Dynamique de l'espace rural et gestion des ressources naturelles en Afrique sahélienne : approche bibliographique. Mémoire de DEA, Université de Lomé, 120 pages.

[7] CEFOD (2004). Recueil de textes sur le droit foncier au Tchad. Banque des données juridiques « le droit par les textes », mars 2004, 109 pages.

[8] CLAUDE, D. (2002). Les anciennes coutumes pénales au Tchad, Paris, Edition l'Harmattan. Conflits intercommunautaires: véritables freins au développement. Chroniques des Libertés et droits fondamentaux $\mathrm{n}^{\circ} 41,2001$, p 5 .

[9] DAGOU P. MAHAMAT Ali Mustapha, BACHIMON P., RISER J (2005). Géosystemes lacustres Etude des régions des lacs Léré et Fitri/Tchad. Rapport du Projet CAMPUS N: 97319107 fac n99 002600

[10] DANGAR, Y. M. (2006). Résolution des conflits dans les milieux traditionnels au Tchad. Actes du colloque de N'Djaména du 3 au 6 juillet 2006, CEFOD, p 23-37.

[11] DJIKOLOUM, B.B. (2004). Analyse critique du droit foncier tchadien. Contribution au colloque sur la question foncière au Tchad du 28 juin au $1^{\text {er }}$ juillet 2004, CEFOD, p 39- 54.

[12] HAGUENBUCHER, F. (1968). Notes sur les Bilala du Fitri. Cahiers ORSTOM, séries sciences humaine v. 4-1968, 37 pages.

[13] KAIDALlaH, M-H. (1985). Les Bilala, leur histoire et leur civilisation. Mémoire de l'ENA de N'Djaména, 62 pages.

[14] KOYOUMTAN, Agard (2002). Les activités rurales et la gestion foncière autour du lac Fitri. Mémoire de maîtrise de géographie, Université de N'Djaména, 101 pages.

[15] LE BRIS, E. ; LE ROY, E. et LEIMDORFER, F. (1982). Enjeux fonciers en Afrique noire, ORSTOM, édition Karthala, Paris, 425 pages.

[16] MAGRIN G. 2002. Le sud du Tchad en mutations : des champs de coton à la sirène de l'or noir. Thèse de doctorat. Université Panthéon-Sorbone Paris I, France.

[17] MARTY et al. (2010). Causes des conflits liés à la mobilité pastorale et mesures d'atténuation. Rapport d'étude de la DOPSSP, 123 pages. www.plateforme-pastorale-tchad.org consulté le 10 mars 2015.

[18] SOUNGABE, P. (2004). Les causes de la recrudescence des conflits entre agriculteurs et éleveurs dans les zones de savane du Tchad. Une étude comparée de deux régions : le Moyen-Chari et le Mayo-Kebbi. Actes de l'atelier régional des pays de l'Afrique de l'Ouest sur les conflits autour de l'utilisation et la gestion des ressources agricoles et pastorales, Niamey, nov. 2004.

[19] ZAKINET Danbet Isidore (2008). La mobilité pastorale au Batha (Tchad central), enjeux et défis : essais d'approche historique, mémoire de master en Histoire, Université Pierre Mendes France de Grenoble, 226 pages. 